\title{
SUATU KAJIAN UMUM \\ TENTANG PENYELESAIAN SENGKETA INTERNASIONAL TERMASUK DI DALAM TUBUH ASEAN
}

\author{
Dewa Gede Sudika Mangku \\ Universitas Pendidikan Ganesha Singaraja \\ e-mail: dewamangku.undiksha@gmail.com
}

\begin{abstract}
ABSTRAK
Tujuan dari penulisan ini adalah untuk memberikan penjelasan secara umum tentang metode atau cara-cara penyelesaian sengketa dalam lingkup internasional yang sedang dihadapi oleh negara-negara. Terdapat berbagai cara bagi suatu negara untuk menyelesaikan suatu sengketa internasional dan tergantung kepada masing-masing negara tersebut untuk cara penyelesaiannya apakah memilih penyelesaian dengan melalui cara damai atau sengketa tersebut akan diselesaikan dengan membawanya ke muka pengadilan internasional. Pada prinsipnya untuk penyelesaian sengketa dalam lingkup internasional baik melalui jalan damai atau melalui pengadilan internasional, negara lain yang tidak berkepentingan terhadap sengketa tersebut tidak diperkenankan untuk ikut campur dalam penyelesaian sengketa internasional tersebut dalam bentuk apapun.
\end{abstract}

Kata Kunci: penyelesaian sengketa internasional, prinsip, metode.

\begin{abstract}
The purpose of this paper is to provide a general description about the method or means of international dispute resolution that being faced by countries. There are various ways for a country to choose the way their international dispute to be settled and it depends on each country to choose the resolution methods, whether the dispute will be resolved through the international tribunal or through peaceful means. Principally, for the settlement of international disputes which is done through peaceful means or through the international tribunal, other countries which are not related to the dispute are not allowed to interfere other countries international disputes settlement progress in any form.
\end{abstract}

Keywords: international dispute settlement, principal, method.

\section{PENDAHULUAN}

Dalam dunia internasional menjalin hubungan internasional adalah suatu hal mutlak yang tidak bisa dihindari oleh setiap negara, hal ini sudah tertuang di dalam Konvensi Montevideo 1933 yang menyatakan syarat dari terbentuknya negara salah satu poin yang paling penting adalah mampu menjalin hubungan internasional dengan negara lain, tujuannya adalah adanya saling membutuhkan satu negara dengan negara lainnya, karena tidak ada satu negara yang dapat memenuhi kebutuhan negaranya sendiri tanpa bantuan dari negara lain. Dengan seringnya negara menjalin hubungan internasional dengan negara lain banyak dampak positif yang dihasilkan dan tidak dipungkiri lagi selain dampak positif yang didapatkan sisi negatifnya pun ada, misalkan suatu negara terlibat suatu pertikaian atau sengketa internasional di antara kedua negara, banyak kasus yang sering menyebabkan ketegangan di antara negara yang bertikai dan banyak kasus yang terjadi yang menyebabkan masalah di atas, misalkan kasus Sipadan dan Ligitan antara Indonesia dan Malaysia, serta suatu Sengketa Kuil Preah vihear antara Thailand dan Kamboja yang sampai saat ini masih bersitegang untuk mempertahankan argumen masing-masing negara. Dalam kesempatan ini saya sebagai penulis ingin menyampaikan beberapa suatu kajian umum tentang pembagian umum penyelesaian sengketa internasional secara umum dan penyelesaian sengketa di tubuh ASEAN.

\section{PEMBAHASAN}

Kata dispute mengandung pengertian pertikaian atau sengketa dimana keduanya yang dipergunakan 
secara bergantian John G. Merrills (1991:1). John G. Merrills memahami suatu persengketaan sebagai terjadinya perbedaan pemahaman akan suatu keadaan atau obyek yang diikuti oleh pengklaim oleh satu pihak dan penolakan di pihak lainnya. Karena itu, sengketa internasional adalah perselisihan, yang tidak secara eksklusif melibatkan negara, dan memiliki konsekuensi pada lingkup internasional. Persoalan yang timbul adalah apa yang bisa dijadikan sebagai subjek persengketaan. Menurut John G. Merrills subyek dari persengketaan dapat bermacam-macam, mulai dari sengketa mengenai kebijakan suatu negara sampai persoalan perbatasan John G. Merrills (2003: 529). Pada umumnya metode-metode penyelesaian sengketa digolongkan ke dalam dua kategori yaitu cara-cara penyelesaian secara damai dan cara-cara penyelesaian secara paksa atau dengan kekerasan (A.A.S.P. Dian Saraswati, 2007:19).

\section{Penyelesaian Sengketa Secara Damai}

Cara-cara penyelesaian sengketa secara damai dapat dilakukan apabila para pihak telah menyepakati untuk menemukan suatu solusi yang bersahabat. J.G. Starke mengklasifikasikan suatu metode penyelesaian sengketa-sengketa internasional secara damai atau bersahabat yaitu sebagai berikut (J.G. Starke, 2007: 646): arbitrase, penyelesaian yudisial, negosiasi, jasa-jasa baik (good offices), mediasi, konsiliasi, penyelidikan, dan penyelesaian di bawah naungan organisasi PBB. Sementara itu, F. Sugeng Istanto (1998:88), menyatakan bahwa penyelesaian secara damai dapat dilakukan melalui beberapa cara yakni: rujuk, penyelesaian sengketa di bawah perlindungan PBB, arbitrasi dan peradilan. Melihat pandangan kedua ahli hukum di atas maka dapat terlihat bahwa penyelesaian sengketa secara damai pada dasarnya dapat dilakukan berdasarkan:

\section{Arbitrasi}

Arbitrasi adalah sebuah salah satu cara alternatif penyelesaian sengketa yang telah dikenal lama dalam hukum internasional. Dalam penyelesaian suatu kasus sengketa internasional, sengketa diajukan kepara para arbitrator yang dipilih secara bebas oleh pihakpihak yang bersengketa. Menurut F. Sugeng Istanto, arbitrasi adalah suatu cara penyelesaian sengketa dengan mengajukan sengketa kepada orang-orang tertentu, yang dipilih secara bebas oleh pihak-pihak yang bersengketa untuk memutuskan sengketa itu tanpa harus memperhatikan ketentuan hukum secara ketat.

Sementara itu, Moh. Burhan Tsani (1990:109), menyatakan arbitrasi adalah suatu cara penerapan prinsip hukum terhadap suatu sengketa dalam batasbatas yang telah disetujui sebelumnya oleh para pihakpihak yang bersengketa. Sementara itu, Konvensi Den Haag Pasal 37 Tahun 1907 memberikan definisi arbitrasi internasional bertujuan untuk menyelesai sengketa-sengketa internasional oleh hakim-hakim pilihan mereka dan atas dasar ketentuan-ketentuan hukum internasional. Dengan penyelesaian melalui jalur arbitrasi ini negara-negara harus melaksanakan keputusan dengan itikad baik.

Hakikatnya arbitrasi ialah prosedur penyelesaian sengketa konsensual dalam arti bahwa penyelesaian sengketa melalui arbitrasi hanya dapat dilakukan dengan persetujuan negara-negara bersengketa yang bersangkutan. Penyerahan suatu sengketa kepada arbitrasi dapat dilakukan dengan perbuatan suatu compromise, yaitu penyerahan kepada arbitrasi suatu sengketa yang telah lahir atau melalui pembuatan suatu klausul arbitrasi dalam suatu perjanjian sebelum sengketa lahir (clause compromissoire). Penyerahan sengketa kepada arbitrasi dapat dilakukan dengan menempatkannya di dalam perjanjian internasional antara negara-negara yang bersangkutan. Perjanjian internasional itu mengatur pokok sengketa yang dimintakan arbitrasi, penunjukkan tribunal arbitrasi, batas wewenang arbitrasi, prosedur arbitrasi, dan ketentuan yang dijadikan dasar pembuatan keputusan arbitrasi.

Susunan tribunal arbitrasi sangat beranekaragam tergantung pada suatu perjanjian internasional yang mengatur arbitrasi itu. Tribunal arbitrasi dapat terdiri dari seorang arbitrator atau beberapa orang arbitrator, beberapa arbitrator ini dapat merupakan gabungan arbitrator yang telah ditunjuk oleh pihak-pihak yang bersengketa atau gabungan arbitrator yang ditunjuk oleh pihak-pihak yang bersengketa ditambah arbitrator yang dipilih menurut cara-cara tertentu. Wewenang tribunal arbitrasi tergantung pada suatu kesepakatan negara-negara yang bersengketa dalam perjanjian internasional tentang arbitrasi yang bersangkutan.

\section{Penyelesaian Yudisial (Judicial Settlement)}

Penyelesaian yudisial berarti suatu penyelesaian yang dihasilkan melalui suatu pengadilan yudisial internasional yang dibentuk sebagaimana mestinya dengan memperlakukan dari suatu kaidah-kaidah hukum. Peradilan yudisial ini menurut F. Sugeng Istanto juga dapat disamakan dengan suatu peradilan internasional. Peradilan Internasional penyelesaian masalah dengan menerapkan ketentuan hukum yang dibentuk secara teratur. Pengadilan dapat dibagi ke dalam dua kategori yaitu pengadilan permanen dan pengadilan ad hoc atau pengadilan khusus. Pengadilan 
internasional permanen contohnya adalah Mahkamah Internasional (ICJ). Peradilan internasional berbeda dengan arbitrasi internasional dalam beberapa hal, yaitu sebagai berikut: Mahkamah secara permanen merupakan sebuah pengadilan, yang diatur dengan statuta dan serangkaian ketentuan prosedurnya yang mengikat terhadap semua pihak yang berhubungan dengan Mahkamah; Mahkamah memiliki panitera atau register tetap, yang telah menjalankan semua fungsi yang diperlukan dalam menerima dokumendokumen untuk arsip, dilakukan suatu pencatatan dan pengesahan, pelayanan umum Mahkamah, dan bertindak sebagai saluran komunikasi tetap dengan pemerintah dan badan-badan lain; Proses peradilan dilakukan secara terbuka, sementara pembelaanpembelaan dan catatan-catatan dengan pendapat serta keputusan-keputusannya dipublikasikan; Pada prinsipnya Mahkamah dapat dimasuki oleh semua negara untuk proses penyelesaian yudisial segala kasus yang dapat diserahkan oleh negara-negara itu kepadanya dan semua masalah khususnya yang diatur dalam traktat dan konvensi yang berlaku; Pasal 38 Statuta Mahkamah secara khusus menetapkan bentuk hukum yang berbeda-beda yang harus diberlakukan Mahkamah di dalam perkara-perkara dan masalahmasalah yang telah diajukan kehadapannya, tanpa menyampingkan Mahkamah untuk dapat memutuskan suatu perkara ex aequo et bono apabila para pihak setuju terhadap cara tersebut (meskipun bukan ex aequo et bono dalam pengertian yang kaku, prinsipprinsip kepantasan yang diterapkan oleh Mahkamah dalam sejumlah besar perkara beberapa waktu ini yang diajukan kepadanya yang berkenaan dengan suatu penetapan batas-batas maritim dan teritorial); Keanggotaan Mahkamah adalah wakil-wakil dari bagian terbesar suatu masyarakat internasional dan mewakili sistem hukum utama, sejauh hal itu tidak bertentangan dengan pengadilan lain; Dimungkinkan bagi Mahkamah untuk mengembangkan suatu praktek yang konsisten dalam proses-proses peradilannya dan memelihara kesinambungan wawasan terhadap suatu hal yang tidak sesuai jika dilakukan pengadilanpengadilan ad hoc.

Menurut F. Sugeng Istanto (1998:94), peradilan internasional berbeda dengan arbitrase internasional yakni ketentuan yang dijadikan dasar pembuatan keputusan dan sifat acaranya. Peradilan internasional memutuskan masalah yang diajukan kepadanya pada prinsipnya hanya berdasarkan pada ketentuan hukum, sedangkan arbitrasi internasional dapat memutuskan masalah yang diajukan kepadanya dapat berdasarkan ketentuan hukum ataupun berdasarkan kepantasan dan kebaikan dan di samping itu acara dalam peradilan internasional yang pada prinsipnya adalah terbuka, sedangkan arbitrasi internasional adalah tertutup.

\section{Negosiasi}

Negosiasi atau perundingan dapat didefinisikan sebagai upaya untuk dapat mempelajari dan merujuki mengenai sikap yang dipersengketakan agar dapat mencapai suatu hasil yang dapat diterima oleh para pihak yang bersengketa. Apa pun bentuk hasil yang dicapai, walaupun sebenarnya lebih banyak diterima oleh satu pihak dibandingkan dengan pihak yang lainnya.

Negosiasi merupakan suatu teknik penyelesaian sengketa yang paling tradisional dan paling sederhana. Dalam teknik penyelesaian sengketa tidak melibatkan pihak ketiga. Pada dasarnya negosiasi hanya berpusat pada diskusi yang dilakukan oleh pihak-pihak yang terkait. Perbedaan persepsi yang telah dimiliki oleh keduabelah pihak akan diperoleh jalan keluar dan menyebabkan pemahaman atas inti persoalan menjadi lebih mudah untuk dipecahkan. Bilamana jalan keluar ditemukan oleh pihak-pihak, maka akan berlanjut pada pemberian konsesi dari tiap pihak kepada pihak lawan (Jawahir Thontowi dan Pranoto Iskandar, 2006: 226). Karena itu, dalam hal salah satu pihak bersikap menolak kemungkinan negosiasi sebagai salahsatu cara penyelesaian ini akan mengalami jalan buntu. Di dalam melakukan negosiasi para pihak harus bisa bersifat universal, harus memenuhi aturan-aturan tentang niat baik, dan tidak sekedar dilaksanakan secara formalitas.

Negosiasi atau perundingan merupakan suatu pertukaran-pertukaran pendapat atau usul-usul antar pihak yang bersengketa untuk mencari kemungkinan tercapainya penyelesaian sengketa secara damai, sedangkan pokok perundingan biasanya merupakan apa yang menjadi pokok dari sengketa internasional yang telah melibatkan pihak-pihak perundingan. Negosiasi merupakan suatu proses yang di dalamnya secara eksplisit diajukan usul secara nyata untuk tercapainya suatu persetujuan (Mirza Satria Buana, 2007:88). Negosiasi juga melibatkan diskusi langsung antarpihak-pihak dalam sengketa, tidak ada pihak luar atau ketiga yang terlibat dalam proses negosiasi.

Segi positif dari suatu negosiasi ini adalah sebagai berikut: Para pihak sendiri yang melakukan negosiasi (perundingan) secara langsung dengan pihak lainnya; Para pihak memiliki kebebasan untuk menentukan bagaimana penyelesaian sengketa secara negosiasi ini dilakukan menurut kesepakatan bersama; Para pihak mengawasi atau memantau secara langsung prosedur penyelesaiannya; Negosiasi menghindari 
perhatian publik dan tekanan politik di dalam negeri; Dalam negosiasi, para pihak dapat berupaya mencari penyelesaian yang dapat diterima dan memuaskan para pihak, sehingga tidak ada pihak yang menang dan yang kalah, tetapi diupayakan kedua belah pihak menang; Negosiasi dimungkinkan dapat digunakan untuk setiap penyelesaian sengketa dalam setiap bentuknya, apakah negosiasi secara tertulis, lisan, bilateral, multilateral, dan lain-lain.

Sedangkan, kelemahan utama penggunaan cara negosiasi di dalam penyelesaian sengketa adalah: Pertama, manakala kedudukan dari para pihak tidak seimbang, salah satu pihak kuat sedang pihak yang lain lemah. Dalam keadaan ini, pihak yang kuat berada dalam posisi untuk menekan pihak lainnya. Hal ini acapkali terjadi manakala dua pihak bernegosiasi untuk menyelesaikan sengketa di antara mereka. Kedua, bahwa proses berlangsungnya suatu negosiasi acapkali lambat dan memakan waktu lama. Hal ini terutama dikarenakan suatu permasalahan antarnegara yang timbul. Selain itu juga, jarang sekali adanya persyaratan penetapan batas waktu bagi para pihak untuk menyelesaikan sengketanya melalui negosiasi. Ketiga, manakala salahsatu pihak terlalu keras dengan pendiriannya, keadaan ini dapat mengakibatkan proses negosiasi menjadi tidak produktif.

Sementara itu juga, menurut F. Sugeng Istanto (1998:89), negosiasi adalah penyelesaian sengketa melalui usaha-usaha penyesuaian pendapat antara pihak-pihak yang bersengketa secara bersahabat. Negosiasi ini merupakan sarana untuk menetapkan penyesuaian kebijakan atau sikap tentang masalah yang disengketakan. John G. Merrills (1991:27), menggambarkan peranan penting lembaga negosiasi ini dengan kalimat sebagai berikut: dalam praktiknya, negosiasi acapkali dimanfaatkan daripada cara-cara lain, seringkali pula negosiasi hanya satu-satunya cara yang dipakai, bukan karena cara ini yang pertama ditempuh, tetapi karena seringkali negara-negara merasakan keuntungannya meskipun sengketanya sudah begitu rumit dan sulit didamaikan. Negosiasi merupakan sebuah metode penting dan pada umunya merupakan persoalan-persoalan yang serius yang dalam praktek harus didahulukan oleh pertukaran diplomatik dan/atau diplomatic exchanges terlebih dahulu.

\section{Mediasi}

Mediasi sebenarnya merupakan bentuk lain dari negosiasi sedangkan yang membedakannya adalah terdapat keterlibatan pihak ketiga. Dalam hal pihak ketiga yang hanya bertindak sebagai pelaku mediasi atau mediator komunikasi bagi pihak ketiga untuk mencarikan negosiasi-negosiasi, maka peran dari pihak ketiga disebut sebagai good office. Seorang mediator merupakan pihak ketiga yang memiliki peran yang aktif untuk mencari solusi yang tepat untuk melancarkan terjadinya kesepakatan antara pihakpihak yang bertikai dan untuk menciptakan adanya suatu kontak atau hubungan langsung di antara para pihak. Tujuannya adalah untuk menciptakan adanya suatu kontak atau hubungan langsung di antara para pihak. Mediator bisa negara, individu, dan organisasi internasional.

Para mediator ini dapat juga bertindak baik atas inisiatifnya sendiri, menawarkan jasanya sebagai mediator, atau menerima tawaran untuk menjalankan fungsi-fungsinya atas permintaan dari salah satu atau keduabelah pihak yang bersengketa. Dalam hal ini, agar mediator dapat berfungsi diperlukan kesepakatan atau konsensus dari para pihak sebagai prasyarat utama.

Di dalam menjalankan fungsinya, mediator tidak tunduk pada suatu aturan-aturan hukum acara tertentu. Mediator juga bebas menentukan bagaimana proses penyelesaian sengketanya berlangsung. Peranannya disini tidak semata-mata hanya mempertemukan para pihak saja agar bersedia berunding, akan tetapi mediator juga terlibat dalam perundingan dengan para pihak dan bisa pula memberikan saran-saran atau usulan-usulan. Di dalam melakukan negosiasi atau perundingan, mediator dapat mengajukan beberapa opsi atau penawaran mengenai penyelesaian masalah sengketa. Adakalanya penawaran mediasi ditolak dan adakalanya juga dapat diterima oleh pihak-pihak yang bersengketa. Keberhasilan proses mediasi tergantung pada kemauan para pihak atau parties willingness to solved issues dan penerimaan serta implementasi penyelesaian yang disarankan atau approval and implement dispute settlement. Proses mediasi bisa dikatakan berhasil apabila usulan, penawaran atau peranan mediator dapat diterima oleh para pihak yang bersengketa. Bahkan mediator dapat pula berupaya mendamaikan para pihak yang bersengketa. Tetapi saran-saran atau pun usulan-usulan mediator tidak mempunyai daya mengikat dan/atau binding power. Jadi, mediator hanya berperan untuk mendamaikan tuntutan kepentingan yang saling berlawanan serta meredam rasa dendam yang mungkin timbul antara pihak-pihak yang bersengketa.

Mediator dalam menerapkan hukum tidak dibatasi pada hukum yang ada. Mediator dapat menggunakan asas ex aequo et bono atau kepatutan dan kelayakan, karena sifatnya ini, cara penyelesaian sengketa melalui mediasi dapat lebih cocok digunakan untuk sengketa- 
sengketa yang sensitif. Sengketa tersebut termasuk di dalamnya adalah sengketa yang memiliki unsur politis, di samping itu sudah barang tentu sengketa hukum.

Menurut Bindshedler (Rudolf L. Bindschedler, 1981:34), ada beberapa segi positif dari mediasi, adalah sebagai berikut: Mediator sebagai penengah dapat memberikan usulan-usulan kompromi di antara para pihak; Mediator dapat memberikan usaha-usaha atau jasa-jasa lainnya, seperti memberi bantuan dalam melaksanakan suatu kesepakatan, bantuan keuangan, mengawasi pelaksanaan kesepakatan, dan lain-lain; Apabila mediatornya adalah sebuah negara, biasanya negara tersebut dapat menggunakan pengaruh dan kekuasaannya terhadap para pihak yang bersengketa untuk mencapai penyelesaian sengketanya; Negara sebagai mediator biasanya memiliki fasilitas teknis yang lebih memadai daripada orang-perorangan.

Sedangkan jika dilihat dari segi negatif mediasi adalah mediator yang dapat saja dalam melaksanakan fungsinya lebih memperhatikan pihak lainnya. Proses penyelesaian sengketa melalui mediasi ini hampir mirip dengan konsilisasi. Perbedaannya, pada mediasi umumnya mediator memberikan usulan penyelesaian secara informal dan usulan tersebut didasarkan pada laporan yang diberikan oleh para pihak, tidak dari hasil penyelidikan sendiri. Perlu ditekankan disini, bahwa saran atau usulan penyelesaian yang diberikan tidaklah mengikat sifatnya, dimana sifatnya hanya berupa rekomendatif atau usulan saja.

\section{Konsiliasi}

Menurut J. G. Starke (1991:673), istilah konsiliasi mempunyai suatu arti yang luas dan sempit. Dalam pengertian luas, konsiliasi mencakup berbagai ragam metode dimana suatu sengketa diselesaikan secara damai dengan bantuan negara-negara lain atau badanbadan penyelidik dan komite-komite penasihat yang tidak berpihak. Dalam pengertian sempit, konsiliasi berarti penyerahan suatu sengketa kepada sebuah komisi atau komite untuk membuat laporan beserta usulan-usulan kepada para pihak bagi penyelesaian sengketa tersebut, usulan itu tidak memiliki sifat mengikat.

Menurut Hakim Manly O. Hudson (Rudolf L. Bindschedler, 1981:35), konsiliasi adalah merupakan suatu proses-proses penyusunan dari usulan-usulan penyelesaian setelah diadakan suatu penyelidikan mengenai fakta-fakta dan suatu upaya-upaya untuk mencari titik temu dari pendirian-pendirian yang saling bertentangan, para pihak dalam sengketa itu tetap bebas untuk menerima atau dapat menolak proposal-proposal yang dirumuskan tersebut.
Menurut Bindschedler (1981:35), penyelesaian sengketa melalui cara konsiliasi juga melibatkan pihak ketiga atau konsiliator yang tidak berpihak atau netral dan keterlibatannya karena diminta oleh para pihak. Unsur ketidakberpihakan dan kenetralan merupakan kata kunci untuk keberhasilan fungsi konsiliasi, hanya dengan terpenuhinya dua unsur ini, objektifitas dari konsiliasi dapat terjamin.

Konsiliasi menurut the Institute of International Law melalui the Regulations on the Procedure of International Conciliation yang telah diadopsinya pada tahun 1961 dalam Pasal 1 dinyatakan, sebagai suatu metode dari penyelesaian sengketa bersifat internasional di dalam suatu komisi yang dibentuk oleh pihak-pihak, baik sifatnya permanen atau ad hoc (sementara) berkaitan dengan proses penyelesaian sengketa. Proses seperti ini berupaya mendamaikan pandangan-pandangan para pihak yang bersengketa meskipun usulan-usulan penyelesaian yang dibuat oleh konsiliator sifatnya tidak mempunyai kekuatan hukum.

The Hague Convention for the Pacific Settlement of International Dispute of 1899 dan 1907 memuat suatu mekanisme dan aturan pembentukan komisi konsiliasi. Badan seperti ini hanya bisa dibentuk dengan persetujuan bersama-sama para pihak. Pada umumnya, badan ini diberi mandat untuk mencari dan melaporkan fakta-fakta yang ada di sekitar pokok sengketa.

\section{Jasa-jasa Baik (Good Offices)}

Jasa-jasa baik diartikan sebagai suatu tindakan pihak ketiga yang akan mencoba membawa ke arah terselenggaranya suatu perundingan atau memberikan fasilitas ke arah terselenggaranya perundingan dengan tanpa berperan serta dalam diskusi mengenai substansi atau pokok sengketa yang bersangkutan. Dalam jasajasa baik, pihak ketiga hanyalah sebagai fasilitator dan menawarkan saluran komunikasi supaya dapat dimanfaatkan oleh para pihak yang bersengketa demi terlaksananya proses perundingan.

Keikutsertaan pihak ketiga memberikan jasa-jasa baik memudahkan pihak yang bersengketa untuk bersama-sama mempercepat perundingan di antara mereka. Setiap pihak yang bersengketa dapat meminta kehadiran jasa-jasa baik. Namun, pihak lainnya tidak berkewajiban untuk menerima permintaan tersebut. Dengan kata lain, permintaan tersebut sifatnya tidak mengikat dan tidak boleh dipandang sebagai tindakan yang tidak bersahabat atau unfriendly act.

Dalam jasa-jasa baik, seorang pihak ketiga hanya memberikan jasa-jasanya untuk mempertemukan pihak-pihak yang bersengketa dan menyarankan 
penyelesaiannya (secara umum), dan tanpa secara nyata ikut serta dalam perundingan atau melakukan penyelidikan yang sangat mendalam mengenai aspekaspek sengketa tersebut itu. Negara atau organisasi internasional yang bertindak untuk memberikan jasajasa baik berarti telah menunjukkan keinginannya yang bersahabat untuk meningkatkan penyelesaian sengketa. Apabila pihak ketiga telah mempertemukan pihak-pihak yang telah bersengketa untuk mencari penyelesaian suatu sengketa, maka selesailah sudah tugas pihak ketiga tersebut.

\section{Pencarian Fakta (Inquiry)}

Ketika terjadi pertikaian mengenai fakta dari suatu persoalan, metode inquiry dapat dipandang paling tepat. Sebab metode ini digunakan untuk mencapai penyelesaian sebuah sengketa dengan cara mendirikan sebuah komisi atau badan yang bersifat internasional untuk mencari dan mendengarkan semua bukti-bukti yang relevan dengan permasalahan kemudian. Dengan dasar bukti-bukti dan permasalahan yang timbul badan ini akan dapat mengeluarkan sebuah fakta yang disertai dengan penyelesaiannya.

Tujuan dari pencarian fakta untuk mencari fakta yang sebenarnya adalah: membentuk suatu dasar bagi penyelesaian sengketa di antara dua negara, yaitu mengawasi pelaksanaan dari suatu perjanjian internasional, memberikan informasi guna membuat putusan di tingkat internasional. Pencarian fakta oleh J. G. Starke, disarankan dengan istilah penyelidikan, tujuan dari penyelidikan tanpa membuat rekomendasirekomendasi yang spesifik adalah untuk menetapkan fakta yang mungkin diselesaikan dan dengan cara demikian memperlancar suatu penyelesaian sengketa yang dirundingkan.

\section{Penyelesaian Sengketa Secara Paksa atau Dengan Kekerasan}

Apabila negara-negara tidak dapat mencapai suatu kesepakatan untuk menyelesaikan sengketa-sengketa mereka secara damai maka cara pemecahan yang mungkin adalah dengan melalui cara-cara kekerasan. Prinsip-prinsip cara penyelesaian melalui kekerasan adalah sebagai berikut:

\section{Perang dan Tindakan Bersenjata Non Perang}

Menurut F. Sugeng Istanto, pertikaian bersenjata atau perang adalah suatu pertentangan yang disertai penggunaan kekerasan angkatan bersenjata masingmasing pihak dengan tujuan menundukkan lawan dan menetapkan persyaratan perdamaian secara sepihak. Sementara itu, menurut J. G. Starke, keseluruhan tujuan dari perang adalah untuk dapat menaklukkan negara lawan dan untuk membebankan syarat-syarat penyelesaian dimana negara yang ditaklukkan itu tidak memiliki alternatif lain selain mematuhinya.

\section{Retorsi}

Menurut J.G. Starke, retorsi adalah istilah teknis untuk pembalasan dendam oleh suatu negara terhadap tindakan-tindakan tidak pantas atau tidak patut dari negara lain, balas dendam tersebut dilakukan dalam bentuk tindakan-tindakan sah yang tidak bersahabat di dalam konferensi negara yang kehormatannya telah dihina, misalnya merenggangnya hubunganhubungan diplomatik, pencabutan privilege-privilege diplomatik, atau penarikan diri dari konsensi-konsensi fiskal dan bea.

Sementara itu, menurut F. Sugeng Istanto (1998: $150)$, keadaan yang membenarkan penggunaan retorsi sampai saat kini belum dapat secara pasti ditentukan karena pelaksanaan retorsi sangat beranekaragam. Penggunaan retorsi secara sah oleh negara anggota PBB nampak terikat dengan ketentuan Piagamnya. Pada Pasal 2 ayat 3 Piagam PBB menetapkan bahwa anggota PBB harus menyelesaikan sengketa yang mereka hadapi dengan cara damai sehingga tidak mengganggu perdamaian dan keamanan internasional dan keadilan.

\section{Tindakan-Tindakan Pembalasan (Reprisal)}

Menurut pemikiran dari Richard B. Lilich (1980: 130), pembalasan adalah suatu metode-metode yang dipakai oleh negara-negara untuk mengupayakan diperolehnya ganti kerugian dari negara-negara lain dengan melakukan tindakan-tindakan yang sifatnya pembalasan. Sementara itu juga, F. Sugeng Istanto, memberikan definisi reprisal adalah pembalasan yang dilakukan oleh suatu negara terhadap tindakan yang melanggar hukum dari negara lawan dalam suatu sengketa. Reprisal berbeda dengan retorsi karena perbuatan retorsi hakikatnya merupakan perbuatan yang tidak melanggar hukum sedangkan perbuatan reprisal pada hakikatnya merupakan perbuatan yang melanggar hukum.

Reprisal di suatu masa perang adalah perbuatan pembalasan antara pihak yang berperang dengan tujuan untuk memaksa pihak lawan menghentikan perbuatannya yang telah melanggar hukum perang. Misalnya, pada tahun 1939 sampai 1940 Inggris menahan barang-barang eksport Jerman yang dimuat kapal netral sebagai pembalasan atas perbuatan tidak sah yang penenggelaman kapal dagang oleh ranjau yang dipasang angkutan laut Jerman.

\section{Blokade Secara Damai (Pacific Blockade)}

Pada waktu perang, blokade terhadap pelabuhan suatu negara yang telah terlibat perang sangat lazim dilakukan oleh angkatan laut. Namun, blokade secara 
damai adalah suatu tindakan yang dilakukan pada waktu damai. Sementara itu menurut pendapat dari F. Sugeng Istanto, blokade adalah suatu pengepungan wilayah, digolongkan sebagai suatu pembalasan, tindakan itu pada umumnya ditujukan untuk memaksa negara yang pelabuhannya diblokade untuk menaati permintaan ganti rugi kerugian yang diderita oleh negara yang memblokade.

Blokade yang secara damai untuk pertama kalinya dilakukan pada tahun 1872 , karena pada tahun itu telah dilakukan sekitar 20 tindakan demikian (Walter R. Thomas, 1980:198). Blokade secara damai pada umumnya dapat digunakan oleh negara-negara yang lemah, meskipun karena itu besar kemungkinan terjadi penyalahgunaan dalam sebagaian besar kasus blokade secara damai dapat dipakai oleh negara-negara besar yang bertindak secara bersama-sama untuk tujuan kepentingan dari negara-negara yang bersangkutan, misalnya untuk mengakhir kerusuhan atau untuk mencegah terjadinya perang.

\section{Intervensi}

Perkataan intervensi seringkali dipakai secara umum untuk menunjukkan hampir semua tindakan campurtangan oleh suatu negara dalam urusan negara lain. Menurut suatu pengertian yang lebih khusus intervensi itu terbatas pada tindakan mencampuri urusan dalam negeri atau luar negeri dari negara lain yang melanggar kemerdekaan negara itu, bukanlah satu intervensi suatu pemberian nasehat oleh suatu negara pada suatu negara lain mengenai beberapa hal yang terletak di dalam kompetensi dari negara yang disebut kemudian untuk mengambil keputusan untuk dirinya, walaupun pada umumnya orang mengangap itu sebagai suatu intervensi. Campurtangan harus berbentuk suatu perintah, yaitu bersifat memaksakan atau ancaman kekerasan berdiri dibelakangnya (J. L. Brierly, 1996:256), campurtangan tersebut hampir selalu disertai dengan suatu bentuk atau implikasi tindakan untuk mengganggu kemerdekaan politik negara bersangkutan.

\section{Penyelesaian Sengketa melalui Kerangka Regional ASEAN: The Treaty of Amity and Cooperation in Southeast Asia 1976 (TAC)}

Preambul pada Deklarasi Bangkok yang memuat tujuan ASEAN yaitu meletakkan dasar atau fondasi yang kokoh untuk memajukan kerjasama regional, memperkuat stabilitas ekonomi, dan stabilitas sosial serta memelihara suatu perdamaian dan keamanan di kawasan Asia Tenggara (Faustinus Andrea, 2006:183). Termasuk dalam tujuan tersebut adalah keinginan menyelesaikan sengketa di antara anggotanya secara damai tanpa menggunakan suatu cara-cara kekerasan atau dengan menggunakan perang.

Salah satu instrumen yang penting dalam upaya mewujudkan dan menciptakan stabilitas politik dan keamanan di dalam kawasan Asia Tenggara adalah the Treaty of Amity and Cooperation in Southeast Asia 1976 (TAC). Pada dasarnya prinsip-prinsip yang terkandung di dalam TAC juga tercermin di dalam Piagam PBB antara lain prinsip non-interference (non-intervensi) dan penggunaan cara-cara damai dalam menyelesaikan sengketa tanpa menggunakan kekerasan yang dapat timbul di antara negara-negara penandatangan TAC.

Sementara, Second protocol amending the Treaty of Amity and Cooperation in Southeast Asia 1998 (Protokol ke-2 amandemen TAC) yang ditandatangani para Menteri Luar Negeri ASEAN dan Papua New Guinea di Manila, 25 Juli 1998 menjadi titik awal perluasan TAC ke luar ASEAN. Upaya ASEAN untuk mempertahankan perdamaian dan stabilitas regional mengalami kemajuan pesat pada bulan Oktober 2003 dengan aksesi yang dilakukan oleh Pemerintah China dan India terhadap TAC pada KTT ASEAN ke-9 di Bali pada tahun 2003. Pemerintah Jepang dan Pakistan mengaksesi TAC pada tanggal 2 Juli 2004 saat AMM ke-37 di Jakarta. Sedangkan Pemerintah Rusia dan Korea Selatan mengaksesi pada Pertemuan Tingkat Menteri (PTM) ASEAN-Rusia dan PTM ASEAN Korsel pada bulan Nopember 2004 di Vientiane, Laos. Selandia Baru dan Mongolia pada AMM ke-38 mengaksesi TAC pada bulan Juli 2005 di Vientiane. Australia mengaksesi TAC pada bulan Desember 2005 di Kuala Lumpur sebelum penyelenggaraan KTT ASEAN ke-11.

Pada KTT ASEAN yang keduabelas, Pemerintah Perancis dan Timor Leste mengaksesi TAC. Aksesi Perancis ke dalam TAC merupakan pengakuan yang penting salahsatu negara Uni Eropa (UE) terhadap eksistensi ASEAN dan pentingnya pengembangan kerjasama dengan ASEAN. UE juga telah menyatakan niatnya untuk mengaksesi TAC yang menandakan kemajuan ASEAN sebagai organisasi regional yang signifikan, khususnya bagi perkembangan kerjasama kedua kawasan. Proses lebih lanjut menyangkut aksesi ini masih terus berkembang. Aksesi Pemerintah China, Rusia, dan Perancis yang merupakan negara anggota tetap Dewan Keamanan PBB menandakan dukungan yang signifikan terhadap TAC sebagai suatu tata tertib atau code of conduct dalam menjalankan hubungan antar negara di dalam dan luar kawasan ASEAN. ASEAN terus mendorong negara-negara lain di luar kawasan untuk mengaksesi TAC. 
Mukadimah di dalam TAC menyatakan bahwa setiap pertikaian atau sengketa yang telah timbul antarnegara anggota ASEAN harus dapat menghindari penggunaan cara kekerasan yang mungkin dapat membahayakan dan dapat menghambat kerjasama dalam kawasan Asia Tenggara. TAC juga memuat tujuan dan juga prinsip-prinsip yang dianut dalam kerangka persahabatan dan kerjasama antarnegara anggota ASEAN. Tujuan dari TAC sebagaimana yang tercantum dalam Bab I Pasal 1 yang menyatakan bahwa untuk dapat mempromosikan perdamaian secara terus menerus, menjalin persahabatan serta kerjasama yang baik di antara negara anggota-anggota ASEAN.

TAC yang ditandatangani pada pertemuan puncak ASEAN pertama di Bali, pada tanggal 24 Februari 1976 sering disebut sebagai wujud dari nilai-nilai global yang mendasari pembentukan suatu organisasi regional. Dalam pertemuan di Bali tersebut, negaranegara anggota ASEAN sepakat untuk (Bambang Cipto, 2007:23): Saling menghormati kemerdekaan, kedaulatan, dan integritas wilayah semua bangsa; Setiap negara berhak memelihara keberadaanya dari campur tangan, subversi, kekerasan dari kekuatan luar; Tidak mencampuri urusan dalam negara lain; Menyelesaikan perbedaan pendapat dan pertikaian dengan jalan damai; Menolak ancaman penggunaan kekerasan.

Apabila dilihat antara pembukaan dan ketentuanketentuan mengenai tujuan dan prinsip-prinsip dasar yang dianut maka salah satu isu yang diutamakan dalam suatu perjanjian TAC ini adalah mengenai penyelesaian pertikaian atau sengketa yang terjadi antarnegara anggota-anggota ASEAN agar dilakukan dengan suatu cara-cara damai tanpa menggunakan kekerasan atau perang untuk menjaga persahabatan dan kerjasama yang sudah terjalin. Pada bab IV dalam TAC telah mengatur mengenai penyelesaian sengketa secara damai yang terdiri dari 5 (lima) pasal, yakni Pasal 13-17. Berdasarkan bab IV TAC, terdapat 3 (tiga) mekanisme atau prosedur penyelesaian sengketa yang dikenal negara-negara anggota ASEAN, yang dapat meliputi: penghindaran timbulnya sengketa dan penyelesaian melalui negosiasi secara langsung, penyelesaian sengketa melalui The High Council, dan cara-cara penyelesaian sengketa berdasarkan Pasal 33 ayat 1 Piagam PBB.

\section{Piagam ASEAN (ASEAN Charter)}

Piagam ASEAN yaitu sebagai suatu perjanjian internasional yang telah lahir dari rangkaian proses panjang negosiasi. Menyelaraskan dan kemudian dapat menyepakati kepentingan-kepentingan dari kesepuluh negara anggota-anggota ASEAN dalam satu wadah bersama yang mengikat secara hukum hanyalah satu dari sekian banyak usaha diplomasi yang harus dilakukan demi lahirnya Piagam ASEAN. Perdamaian, stabilitas, kemajuan, dan kesejahteraan bersama kawasan antara lain menjadi kepentingan dasar yang pada akhirnya dapat menyatukan negaranegara Asia Tenggara dalam sebuah wadah ASEAN (Eddy Pratomo, 2009:2).

Rangkaian proses panjang negosiasi dapat dilihat antara lain dari penyusunan draft Piagam ASEAN diawali dengan pembentukan Eminent Persons Group on the ASEAN Charter (EPG) yang beranggotakan para tokoh terkemuka dari seluruh negara anggota ASEAN dan diketuai oleh Tun Musa Hitam (EPGMalaysia). Pembentukan EPG ini diresmikan pada KTT ASEAN kesebelas di Kuala Lumpur, Malaysia Desember 2005 dengan ditandatanganinya Kuala Lumpur Declaration on the Establishment of the ASEAN Charter. EPG bertugas untuk memberikan masukan-masukan dan rekomendasi terhadap proses penyusunan draft Piagam ASEAN yaitu selama masa kerjanya tahun 2006 EPG telah melakukan 8 (delapan) kali pertemuan yang antara lain juga melakukan dialog dengan Kepala Negara atau Pemerintahan, Sektor Bisnis, Parlemen, dan Civil Society Organizations. Melalui pertemuan-pertemuan ini telah diperoleh masukan dan saran mengenai bagaimana Piagam ASEAN sebaiknya akan disusun (Direktorat Jenderal Kerjasama ASEAN Departemen Luar Negeri RI).

EPG merekomendasi hal-hal antara lain sebagai berikut: Menegaskan agar Piagam ASEAN memuat kejelasan tentang mekanisme dan struktur ASEAN yang efektif dan efisien; Meningkatkan keterlibatan masyarakat di dalam berbagai kegiatan-kegiatan kerjasama ASEAN (people-centered organization); dan dapat Memperkuat pembangunan Komunitas ASEAN.

Kemudian pada KTT ASEAN ke-12 di Cebu, Filipina yang dilaksankan pada bulan Januari 2007, telah melahirkan suatu kesepakatan antara negaranegara anggota ASEAN tentang ditandatanganinya Cebu Declaration on the Blueprint of the ASEAN Charter (J.S George Lantu, 2008), yang berisi suatu kesepakatan untuk menyusun suatu Piagam ASEAN berdasarkan rekomendasi yang diajukan oleh EPG. Para Kepala Negara atau Kepala Pemerintahan negara anggota-anggota ASEAN telah memberikan arahan mengenai penyusunan piagam serta membentuk suatu High Level Task Force on the Drafting of ASEAN Charter (HLTF) yang beranggotakan para pejabat 
tinggi dari negara-negara anggota ASEAN. Sesuai mandatnya seluruh para anggota HLTF ditugaskan untuk dapat menyelesaikan penyusunan draft ASEAN Charter sebelum KTT ASEAN ke-13 di Singapura yang dilaksanakan pada bulan November 2007. KTT ASEAN ke-13 di Singapura tersebut telah mencatat sejarah baru bagi negara-negara anggota di kawasan Asia Tenggara. Sejarah baru tersebut adalah dengan terbentuknya sebuah Piagam ASEAN yang telah ditandatangani oleh para pemimpin negara-negara anggota ASEAN pada tanggal 20 November 2007 dan mulai diberlakukan sejak tanggal 15 Desember 2008 (Anonim, http://www.koranindonesia.com/2007/ 12/26/berharap-pada-piagam-asean).

Piagam ASEAN yang telah ditandatangani dan diratifikasi oleh seluruh negara anggota ASEAN kemudian akan mengubah ASEAN dari organisasi kawasan yang longgar menjadi sebuah organisasi yang berdasarkan aturan yang profesional atau rulesbased organisation. Keberadaan Piagam ASEAN akan memberikan suatu kerangka hukum dan institusional bagi ASEAN untuk dapat berkembang ke arah sebuah komunitas bersama yang mengedepankan antara lain yaitu perdamaian, keamanan, stabilitas, pertumbuhan ekonomi berlanjut, kesejahteraan serta kemajuan sosial.

Piagam ASEAN terdiri dari empat belas bagian besar termasuk pembukaan yang memuat dasar-dasar pembentukan Piagam ASEAN tersebut. Empat belas bagian besar tersebut kemudian diturunkan ke dalam 55 (lima puluh lima) pasal yang mengatur tidak saja organisasi ASEAN melainkan juga aturan-aturan umum yang harus dapat digunakan oleh para anggota ASEAN dalam berinteraksi di kawasan ASEAN salah satunya adalah mekanisme penyelesaian sengketa dalam kerangka regional ASEAN.

Bagian dari Piagam ASEAN yang menjadi pusat dari seluruh bagian lainnya adalah bagian pertama, yaitu tujuan dan prinsip. Bagian ini memuat 15 (lima belas) tujuan Piagam ASEAN dan 14 (empat belas) prinsip ASEAN yang harus dihormati oleh seluruh negara anggota ASEAN. Dapat dikatakan juga bahwa bagian tujuan dan prinsip ini adalah prinsip-prinsip dasar ASEAN yang telah terbentuk, berevolusi, dan menjadi kebiasaan ASEAN sejak tahun 1967 sampai dengan sekarang.

Pada bagian-bagian pembukaan dari Piagam ASEAN dinyatakan bahwa dengan menghormati persahabatan dan kerjasama serta prinsip-prinsip yang terdapat dalam TAC dengan beberapa prinsipprinsip tambahan yaitu bersatu dalam perbedaan serta konsensus. Dalam konteks regional ASEAN, ada beberapa prinsip penyelesaian sengketa yang dituangkan dalam beberapa instrumen hukum dan Piagam ASEAN. Dalam konteks tersebut, mekanisme penyelesaian sengketa yang ditekankan di ASEAN lebih memilih cara-cara damai, sebab selain hal itu menguntungkan para pihak yang bersengketa, juga berimplikasi positif terhadap stabilitas keamanan di wilayah kawasan. Selain itu, faktor sejarah ASEAN yang lahir karena keprihatinan yang timbul kala itu, dimana negara-negara di kawasan ini sangat rentan konflik yang melibatkan kepentingan negara-negara besar pasca Perang Dunia II, sehingga Asia Tenggara pernah dijuluki sebagai Balkan-nya Asia.

Atas dasar itulah berbagai perjanjian kerjasama dalam bingkai ASEAN selalu dilakukan dengan cara penekanan pada penggunaan cara-cara damai dalam penyelesaiannya, ketika terjadi sengketa. Hal ini tercemin juga dalam Piagam ASEAN yang sudah ditandatangani dan diberlakukan bagi negara anggotaanggota ASEAN. Menurut pandangan sebagian para ahli, ketentuan pada Pasal 22 sampai dengan Pasal 28 dalam Piagam ASEAN yang mengatur mengenai mekanisme penyelesaian sengketa di ASEAN, yang merupakan repetisi dari Pasal 13 sampai dengan Pasal 17 TAC dan merupakan imitasi dari Pasal 33 Piagam PBB. Hal ini dijelaskan dan ditegaskan dalam Pasal 38 Piagam ASEAN yang merujuk Piagam PBB dalam mekanisme penyelesaian sengketa (Mahmud Syaltout, 2008:28).

Dalam ketentuan pada Pasal 28 Piagam ASEAN ditegaskan, kecuali yang diatur sebaliknya di dalam piagam ini, negara-negara anggota berhak untuk beralih ke cara-cara penyelesaian sengketa secara damai seperti tercantum dalam Pasal 33 ayat 1 dari Piagam Perserikatan Bangsa-Bangsa atau instrumen hukum internasional yang lain yang ada didalamnya negara-negara anggota yang bersengketa merupakan para pihak.

Dalam pasal tersebut ditegaskan ada tiga pilihan model penyelesaian sengketa yang bisa dilakukan oleh para anggota ASEAN. Pertama, para pihak terlebih dulu harus mengupayakan mekanisme penyelesaian sengketa melalui prosedur yang disediakan dalam Piagam ASEAN, sebagaimana telah diuraikan dalam ketentuan Pasal 22 sampai dengan Pasal 28. Kedua, para pihak yang notabenenya juga merupakan anggota PBB dapat menggunakan ketentuan dalam Pasal 33 ayat 1 Piagam PBB dalam penyelesaian sengketa secara damai di antara mereka. Ketiga, selain itu melalui kedua mekanisme tersebut para pihak dapat menggunakan cara-cara penyelesaian sengketa yang diatur dalam ketentuan hukum internasional lainnya 
dimana para pihak yang bersengketa merupakan pihak dari perjanjian tersebut.

Berdasarkan ketentuan di atas, tampak bahwa mekanisme penyelesaian sengketa yang diakui oleh piagam tersebut menggunakan banyak cara yang tersedia di dalam hubungan internasional. Namun demikian, prinsip mendasar yang telah di dorong oleh Piagam ASEAN adalah menggunakan cara-cara damai. Dalam ketentuan Piagam ASEAN tersebut pula ditegaskan, bahwa segala jenis sengketa yang terjadi dalam pelaksanaan kerjasama di kalangan negara anggota ASEAN dapat diselesaikan dengan menggunakan cara-cara yang disebutkan di dalam piagam. Oleh karena itu, Piagam ASEAN tidak hanya membatasi jenis sengketa-sengketa tertentu saja yang bisa diselesaikan melalui mekanisme yang ditentukan oleh piagam. Namun demikian menurut Syaltout, pasal-pasal penyelesaian di dalam Piagam ASEAN tersebut hanya mengatur sengketa-sengketa politik dan diplomatik yang terjadi di ASEAN (Syaltout, 2008:29)

Padahal pada era globalisasi dimana sengketa antarnegara merupakan sengketa perdagangan dan ekonomi, mekanisme penyelesai sengketa ala $\mathrm{PBB}$ bukanlah merupakan suatu jawaban yang baik. Sebab dalam era globalisasi seperti saat ini, suatu sengketa politik dan diplomatik tepatnya geo-politik, tidak mungkin terlepas dari muatan ekonomi dan geoekonomi. Sebagai contoh ialah: sengketa Kuil Preah Vihear, Sipada-Ligitan dan Blok Ambalat, bukan sekedar sengketa politik akan tetapi lebih jauh dari itu, sengketa perbatasan tersebut merupakan sengketa atas kepentingan ekonomi yang berada di atas tanah perbatasan tersebut.

Terlepas dari persoalan tersebut, yang pasti adalah bahwa dalam bentuk apapun obyek sengketa yang terjadi di kalangan anggota ASEAN, Piagam ASEAN sebisa mungkin menekankan untuk menggunakan cara-cara diplomasi dalam penyelesaiannya, seperti negosiasi, konsiliasi, mediasi, jasa baik, dan lain sebagainya yang telah disepakati oleh para pihak. Prinsip ini dipilih semata-mata untuk tetap menjaga stabilitas dan keharmonisan dalam suatu hubungan bilateral antar anggota ASEAN sendiri (Anonim, http: //kapanlagi.com/1;2006). Semenjak ASEAN didirikan dan dideklarasikan di Bangkok pada 8 Agustus 1967 , ASEAN belum memiliki suatu piagam atau charter yang memberikan status hukum atau legal personality, dan dengan diberlakukannya Piagam ASEAN ini, diharapkan minimal akan mengakomodasi berbagai dokumen ASEAN yang sudah ada dan memberikan jatidiri hukum terhadap ASEAN.

\section{Sengketa Kuil Preah Vihear}

Salah satu isu sentral dalam Pertemuan Menteri ASEAN di Singapura, 23 Juli 2008 adalah ketegangan tentara militer antara Kamboja dan Thailand. Kedua negara bersengketa tentang status kepemilikan Kuil Preah Vihear, serta tidak ada kejelasan tentang garis perbatasan wilayah kedua negara. Masalah status kepemilikan kuil sebenarnya sudah lama terjadi. Akar masalah sengketa kuil ini lahir karena ketidakjelasan kesepakatan antara pemerintah Perancis (yang telah menduduki Kamboja) dan Pemerintah Siam (kini Thailand) pada awal tahun 1900. Perancis dan Siam sepakat menetapkan garis batas kedua negara yang dituangkan dalam sebuah Perjanjian Franco-Siamese pada tanggal 13 Februari 1904. Namun, perjanjian ini tidak dengan tegas menetapkan dimana letak Kuil Preah Vihear berada (Kompas, 5 Agustus 2008).

Ketika merdeka pada tahun 1953, negara Kamboja mulai mengangkat permasalahan kepemilikan Kuil Preah Vihear dengan Thailand. Hubungan kedua negara sempat tegang setelah Thailand mengirim tentaranya ke kuil tersebut. Thailand bahkan sempat mengamankan sebagian arca-arca dan obyek kuil ke negerinya. Setelah upaya diplomatik gagal, kedua negara telah sepakat menyerahkan permasalahan ini ke Mahkamah Internasional (MI), dalam putusannya tanggal 15 Juni 1962 (The Hague Judgment of 15 June 1962), Mahkamah Internasional memutuskan bahwa Kamboja sebagai pemilik Kuil Preah Vihear dan akibatnya negara Thailand harus menarik pasukan militernya maupun para penjaga yang dikerahkan di sekitar kuil atau di sekitar wilayah kedaulatan Kamboja.

Keputusan dari Mahkamah Internasional tersebut adalah bersifat mengikat dan final artinya para pihak yang bersengketa di hadapan Mahkamah Internasional tidak dapat melakukan banding atas keputusannya yang telah dikeluarkan. Mahkamah Internasional mendasarkan putusannya pada peta yang telah dibuat sekelompok ahli yang dibentuk atas kesepakatan antara pemerintah Perancis dan pemerintah Siam, yaitu the Commission of Delimitation. Di dalam sebuah keputusannya, Mahkamah Internasional tidak dengan tegas menetapkan garis batas kedua negara. Mahkamah Internasional hanya menetapkan siapa yang memiliki kedaulatan atas kuil tersebut (Media Indonesia, 16 Oktober 2008).

Pada bulan Juli 2008 Kuil Preah Vihear yang diperkirakan yang telah berumur sekitar 900 tahun dimasukkan dalam daftar warisan budaya dunia atau Word Heritage List oleh Organisasi Pendidikan, Ilmu Pengatahuan dan Kebudayaan PBB (UNESCO), hal 
ini disambut gembira oleh Pemerintah Kamboja, namun memicu masalah di Thailand (Sinar Harapan, 7 Oktober 2008) dan hal tersebut menimbulkan kontak senjata antara tentara militer Kamboja dengan tentara militer Thailand di perbatasan dekat Kuil Preah Vihear yang menjadi jantung sengketa antara kedua negara. Baku tembak yang pecah antara tentara militer kedua negara terjadi pada tanggal 15 Oktober 2008 yang mengakibatkan tewasnya dua orang tentara Kamboja dan telah melukai lima orang tentara Thailand, dan kemudian baku tembak untuk kedua kalinya terjadi pada tanggal 3 April 2009, akibat kontak senjata tersebut telah menewaskan dua orang tentara militer Thailand dan mengakibatkan sepuluh orang tentara militer lainnya mengalami luka-luka (Kompas, 16 Oktober 2008). Hingga saat ini kedua negara masih bersitegang atas kuil tersebut.

\section{PENUTUP}

\section{Kesimpulan}

Berdasarkan pemaparan dan penjelasan di atas, dapat diberikan kesimpulan bahwa begitu banyak metode penyelesaian sengketa internasional yang tersedia yang dapat digunakan oleh setiap negara atau masing-masing negara yang tengah dilanda sengketa atau konflik dengan negara lain. Masing-masing negara yang bersengketa berhak untuk menentukan penyelesaian pada sengketa internasional yang mana yang akan digunakan, kesemua ini tergantung dan kesepakatan masing-masing negara dan yang paling penting adalah negara ketiga atau negara lain yang tidak ikut terlibat di dalam sengketa tersebut dilarang untuk ikut campur untuk menangani sengketa yang sedang dihadapi oleh suatu negara, lain halnya jika negara yang sedang bersengketa meminta bantuan kepada negara lain untuk membantu menyelesaikan sengketa tersebut. Begitu juga sengketa yang telah melanda Thailand dan Kamboja, kedua negara berhak untuk menentukan pilihan penyelesaian sengketa yang digunakan untuk mencari solusi demi terciptanya kedamaian di kedua belah pihak.

\section{Rekomendasi}

Dalam penjelasan di atas, adapun rekomendasi yang dapat saya sampaikan sebagai penulis adalah dengan begitu banyaknya metode penyelesaian dari sengketa internasional yang telah ada, setiap negara yang sedang dilanda sengketa atau permasalahan dengan negara lain bebas untuk memilih metode yang ada tentunya berdasakan kesepakan oleh kedua negara yang sedang bertikai. Mengunakan metodemetode penyelesaian sengketa secara damai adalah cara bijak di dalam menyelesaikan suatu permasalahan dan hal ini dapat menciptakan suatu keadaan yang aman dan kondusif kepada para negara-negara yang sedang bersengketa.

\section{DAFTAR PUSTAKA}

\section{Buku:}

Adolf, Huala, 1990, Aspek-aspek Negara dalam Hukum Internasional, Jakarta: Rajawali Pers.

Buana, Mirza Satria, 2007, Hukum Internasional Teori dan Praktek, Kalimantan Selatan: FH Unlam Press.

Brierly, J.L., 1996, Hukum Bangsa-Bangsa Suatu Pengantar Hukum Internasional, Jakarta: Bharatara.

Cipto, Bambang, 2007, Hubungan Internasional di Asia Tenggara, Teropong terhadap Dinamika, Realitas, dan Masa Depan, Yogyakarta: Pustaka Pelajar.

Istanto, Sugeng F., 1998, Hukum Internasional, Yogyakarta: Universitas Atma Jaya.

Merrills, John G., 1991, International Dispute Settlement, Cambridge: Cambridge University Press. Penterjemah Achmad Fausan, Penyelesaian Sengketa Internasional, Bandung: Tarsito. 2003, The Means of Dispute Settlement, Malcom D. Evan (ed.), International Law, New York: Oxford University Press.

O'Brien, John, 2001, Internasional Law, London: Cavendish.

Starke, J. G, 2007, Pengantar Hukum Internasional (edisi kesepuluh, Buku 1), Penerjemah Bambang Iriana Djajaatmadja, Jakarta: Sinar Grafika. , 2007, Pengantar Hukum Internasional (edisi kesepuluh, Buku 2), Penerjemah Bambang Iriana Djajaatmadja, Jakarta: Sinar Grafika.

Suryokusumo, Sumaryo, 2007, Studi Kasus Hukum Internasional, Jakarta: Tatanusa.

Thontowi, Jawahir dan Pranoto Iskandar, 2006, Hukum Internasional Kontemporer, Bandung: Refika Aditama.

Tsani, Burhan Moh., 1990, Hukum dan Hubungan Internasional, Yogyakarta: Liberty.

\section{Jurnal:}

Andrea, Faustinus, 2006, Perimbangan Kekuatan di Myanmar Faktor ASEAN dan Kepentingan Indonesia, Volume. 35 No. 2 Juni 2006, Analisis Centre for Strategic and International Studies (CSIS), Jakarta.

Lantu, George J.S., 2008, Transformasi ASEAN: Bagaimana Piagam Membentuk Komunitas 
ASEAN, Makalah pada Annual Lecture Menghormati Tokoh Diplomasi Mochtar Kusumaatmadja, Universitas Padjajaran, Bandung.

Pratomo, Eddy, 2009, Prospek dan Tantangan Hukum Internasional di ASEAN dan Indonesia Pasca Piagam ASEAN dari Sisi Perjanjian Internasional, Diskusi Panel Fakultas Hukum UII pada tanggal 7 Januari 2009, Yogyakarta.

Saraswati, Dian A.A.S.P., 2007, Simplikasi Pengaruh Pelaksanaan Putusan Mahkamah Internasional dalam Memperluas Wilayah Laut Suatu Negara (Studi Kasus Sengketa Wilayah Ambalat antara Indonesia dengan Malaysia), Tesis Program Studi Ilmu Hukum Jurusan Ilmu-Ilmu Sosial, Program Pascasarjana UGM, Yogyakarta.

Syaltout, Mahmud, 2008, Wajah Lama ASEAN Charter, Jurnal Nasional, 21 Februari 2008.
Thomas, Walter R, 1980, Pacific Blokade, A Lost Opportunity of the 1930's, dalam US Naval War College International Law Studies.

\section{Internet:}

Anonim, 2007, Berharap pada Piagam ASEAN, diakses pada tanggal 11 November 2010 dari http: //www.koranindonesia.com/2007/12/26/berharappada-piagam-asean/.

Anonim, 2006, ASEAN Charter Tidak Jadikan ASEAN Duplikat Uni Eropa, diakses pada tanggal 14 Desember 2010 dari http://kapanlagi.com/

\section{Media Massa:}

Kompas, 5 Agustus 2008.

Media Indonesia, 16 Oktober 2008.

Kompas, 16 Oktober 2008. 